Mouzas, S. (2016). Performance based contracting in long-term supply relationships. Industrial Marketing Management, forthcoming in 2016

\author{
Stefanos Mouzas
}

Lancaster University

\title{
PERFORMANCE BASED CONTRACTING \\ IN \\ LONG-TERM SUPPLY RELATIONSHIPS
}

\begin{abstract}
The study investigates performance-based contracting in long term-supply relationships. Based on an empirical investigation involving manufacturers, retailers, and service providers conducted between September 2010 and March 2013, the present study demonstrates that performance that companies buy and sell can be analyzed as specific combinations of effectiveness, efficiency and risk. While firms engage in a complex and time-consuming process to design and agree upon short-term and long-term performance targets, incentive mechanisms, as well as risks of buying or selling future performance, they often fail in achieving excellence in all performance targets.
\end{abstract}

Key words: Performance, Contracts, Negotiation, Agreements, Incentives

\section{Introduction}

At a time of shifting economic conditions and global competition for resources and market shares, the need for firms to engage in a performance-based contracting is increasing. Indeed, a great deal of government procurement, public-private partnerships (Roehrich \& Caldwell, 2012; Roehrich, Lewis, \& George, 2014) but also business activity in long-term supply relationships in logistics and services (Selviaridis \& Spring, 2010; Essig, 2000; Glas, Hofmann, \& Essig 2013) appears to 
be occurring via inter-firm contracting for procuring complex performance (Araujo \& Spring, 2010; Roehrich, Caldwell \& Lewis, 2014; Caldwell, Roehrich \& Davies, 2009).

Performance-based contracting is about buying and selling solutions for end-users and not about buying or selling transactional products or services (Davies, 2004; Essig, 2003; Roehrich \& Caldwell, 2012; Windahl, et al., 2004; Windahl \& Lakemond, 2006, 2010). Specifically, in long-term supply relationships between manufacturers and retailers, contracting is not about buying certain quantities of consumer products at agreed prices but it is about buying and selling performances that are necessary for end-consumers to be able to purchase the products and services that they demand. I use the term contracting to circumscribe a recurrent, often long-term, process of interdependent exchange relationships (Lusch \& Brown, 1996; Cachon \& Lariviere, 2001; Mouzas \& Blois, 2013). Contracting enables firms to solve problems transforming aspects of their resources, activities and themselves (Spekman, Kamauff, \& Myhr, 1998; Barratt 2004; Kogut \& Zander, 1992; Nickerson \& Zenger, 2004; Selviaridis \& Spring, 2010).

Contracting incorporates a significant element of futurity (Atiyah, 1986). Yet, firms face the problem that they need to anticipate and 'presentiate' (Macneil 1974) future performance and manifest their agreement in a complete contract (Hart \& Moore, 1988; Schwartz, 1992; Baker et al., 2002; Mouzas \& Blois, 2013; Schwartz and Scott, 2015). This problem is evidenced in public procurement, strategic alliances, and R\&D projects (Das \& Teng, 1999, 2000; Reuer \& Arino, 2003, 2007; Roehrich \& Caldwell, 2012; Roehrich et al. 2014); as well as in continuing business relationships (Harrison, 2004; Ring \& Van de Ven, 1992; Roxenhall \& Ghauri, 2004; Scott \& Schwartz, 2015).

Barriers to anticipating future performance are regarded as transaction costs (Williamson, 2008); they are the costs of running "market transactions" or the "costs of using the price mechanism” (Coase, 1988, p.7) akin to the friction in physical systems (Langlois, 2006). Specifically, transaction costs are a function of (1) information asymmetries between counterparts in supply chains and unforeseen contextual contingencies, (2) drafting costs, (3) enforcement costs, and (4) 
renegotiation requirements (Williamson, 2008; Tirole, 1986, 1999, 2009). These formidable barriers have been discussed extensively in previous research under the aegis of the relational and incomplete contract theories (Macneil, 1974; Tirole, 1986; Hart \& Moore, 1989; Schwartz, 1992; Maskin \& Tirole, 1999; Brown et al., 2004; Taylor \& Plambeck, 2007; Poppo \& Zenger, 2002; Reuer \& Arino, 2007; Furlotti, 2007).

Although there is a substantial amount of academic work on barriers to anticipating future performance (Hobbs, 1996; Hobbs and Young, 2000; Cachon \& Lariviere, 2001, 2005; Williamson, 2008), there is a research gap about the ways in which firms attempt to overcome these barriers by developing a performance-based contracting. This may be attributed to a theoretical deficiency about what it means performance, the ingredients that constitute contractual performance and subsequent lack of sufficient empirical research on how firms interact to design and negotiate performance targets, agree upon incentive mechanisms and translate the short-term and long-term effects and risks of fulfilling or breaching performance promises. I posit that one of the missing pieces for a robust explanation of the puzzle of how companies overcome barriers to anticipating future performance is the lack of attention to the complex and time-consuming process of how companies reach consent on performance targets.

The research gap on how firms overcome barriers to anticipating future performance raises new questions about 1) how firms agree upon performance targets, 2) how counterparts manifest their agreement with contract clauses, 3) the incentives and sanctions that enable and compel firms to deliver contractual performance, 4) the compensation that firms receive for bearing risks, 5) the conflicts and incompatibilities in achieving contractual performance. To address this theoretical deficiency, I built on Srivastava, Shervani \& Fahey’s (1998) insight that firms are concerned with resources that are market-based assets, such as customer relationships, channel relationships and partner relationships; and I engaged in a systematic process to structure the existing literature on 'what it means performance' with a conceptual framework of the ingredients that constitute contractual performance (Kotabe, 1998; Mentzer \& Konrad, 1991; Kotler, Jain, \& Maesincee, 2002). 
Based on an empirical investigation, conducted between September 2010 and March 2013 in the context of long-term supply relationships between manufacturers, service providers and grocery retailers, the study offers the following argument: By reaching consent on performance targets, firms seek to balance the need for certainty and calculability of future performance with the need to remain sufficiently flexible to innovate and embrace business opportunities. From the perspective of end-user needs, contracting parties attempt to balance the achievement of contractual effectiveness, in terms of volume, sales or market share with the need to maintain contractual efficiency in terms of controlling cost and operating margins and simultaneously control the contractual risk in terms of probability of adverse impact and compensating for bearing certain contractual risks. Performance can thus be analyzed as specific combinations of effectiveness, efficiency, and risk. This balancing act is challenging and firms often fail to achieve performance outcomes in all three combinations simultaneously.

By providing a theoretical conceptualization of the ingredients of contractual performance and real-life empirical evidence of how companies anticipate future performance, the study attempts to break new ground and provide a major intellectual stimulus on performance-based contracting that is relevant for our understanding of new applications for business practice. The novel contribution that this study makes is particularly useful in analyzing performance-based contracting in continuing business relationships (Ring \& van de Ven, 1999; Das \& Teng, 1999) because firms in these relationships anticipate long-term performance relying on economic incentives (Harris \& Raviv, 1996; Bajari \& Tadelis, 2001; Levin, 2003) and selfreinforcing framework agreements with non-legal sanctions (Bernstein, 1992; Charny, 1990; Scott, 2003; Mouzas \& Blois, 2013; Schwartz \& Scott, 2015).

\section{Performance-based Contracting}

The rapid technological developments and the need to perform cost-competitively in the marketplace, provides an incentive for firms to limit the proportion of the resources that they hold in-house. The resources that companies need are idiosyncratic; and they are not available in a concentrated form, but dispersed in the 
business landscape (Denrell, Fang, \& Winter, 2003; Mouzas et al., 2008; Baraldi \& Stromsten, 2009). Firms engage in contractual relationships with counterparts to access the resources that they need to solve their problems (Spekman, Kamauff, \& Myhr, 1998; Barratt, 2004). A consequence of the technological developments, competitive pressure and ever increasing interdependence is the need for firms to obtain comprehensive solutions for end-users (Essig, 2003; Roehrich \& Caldwell, 2012; Windahl \& Lakemond, 2006, 2010). By designing, negotiating and implementing a performance-based contracting, firms' resources will evolve in relation to each other according to anticipated and agreed performance targets (Selviaridis \& Spring, 2010).

Performance-based contracting is about buying and selling the performance that these resources would render (Essig, 2003; Roehrich \& Caldwell, 2012; Glas, Hofmann, \& Essig, 2013). More profoundly, performance-based contracting has important implications for the nature of resources: A particular resource in the business landscape is not a fixed entity, but is the outcome of its interactions with other resources (Ford \& Mouzas, 2009). In this way, the use and value of services that a resource would render is dependent on the particular combination and characteristics of other resources with which the resource is combined. Some particular resources, such as brands, reputations, patents, market-based assets or know-how can be considered as 'strategic' resources (Amit \& Schoemaker, 1993; Barney, 1986, 1991; Srivastava, Shervani, \& Fahey, 1998) and there is robust empirical evidence that through an exchange process with other firms these resources can enhance business performance (Crook et al., 2008).

Through a performance-based contracting between firms, resources will follow a coevolutionary path of change over time for the benefit of counterparties leading to their growing inter-dependence. Furthermore, each of the negotiated and agreed performances between two counterparts is connected with other firms' performances forming a supply network that gives access to and affects a wide array of more or less distant performances (Gnyawali \& Madhavan, 2001).

By manifesting their consent on performance targets, firms may attempt to increase the reliability and the legal enforcement of specific performances of others. In this 
sense, legally-enforceable contracts are manifestations of consent (McKendrick, 2002) that "circumscribe the valuation of conduct" (Collins, 1999, p 21) and give legal effect to exchange relationships. Consent is an inter-cognitive achievement (Barnett, 1986; Barnett, 1992b; Barnett, 2002) between contracting parties which bring certain property rights Foss \& Foss, 2005) in the sense of entitlements to a system of exchange relationships (Biggart \& Delbridge, 2004). Contracting parties could manifest their consent to performance targets at physical level, monetary level as well as informational or knowledge-based level (Essig \& Arnold, 2001; Mouzas \& Ford, 2012). In this way, consent between counterparts is not simply a mental state but an act in which there is a meeting of wills based on objective manifestations of intent that are legally binding. As a result, the process of contract formation has 'hard edges’ (Atiyah, 1995) which makes it difficult for counterparts to reach and update their consent over time.

The problem that firms face is that it is often impossible for counterparts to manifest their consent in a complete contract and verify contractual performance (Hart \& More, 1988; Schwartz, 1992; Baker et al., 2002). Contract theories attempted to deal with this problem from a 'relational' or 'incomplete' contract perspective (Schwartz, 1992; Tirole, 1999, 2009).

Seeking a performance-based contracting with counterparts under conditions of information asymmetry, unforeseen contingencies and limited verifiability remains a critical and taunting task for business actors. In theory, the value of contracting now is the net present worth of all future benefits and sacrifices taking into account the opportunity cost of capital adjusted by the level of risk that the give-and-take process involves (Che \& Hausch, 1999; Hart, 1995).

In practice, while some elements of a future performance can be certain, "complete, fully contingent, costlessly enforceable contracts are not possible" for two reasons (Klein 1980, p. 356). First, unforeseen contingencies exist and it may be costly or impracticable to specify responses to all of them (Maskin \& Tirole, 1999). This source of contractual incompleteness is also attributed to bounded rationality (Williamson, 1979; Anderlini, \& Felli, 1994; Segal, 1999; Tirole, 2009). Second, it is 
usually expensive or effectively unfeasible for counterparts to measure some types of contractual performance (Hart, 1995; Tirole, 1999). These two reasons might explain why the incomplete contracting focused its attention on the existence of opportunistic transaction costs and not on mundane transaction costs which are the costs of using the market (Baldwin, 2007; Langlois, 2006).

Williamson (1979, 1985) identifies: a) uncertainty; b) frequency; and, c) asset specificity as the three critical dimensions of transactions. Asset specificity, in particular, introduces opportunism as a cost because counterparts' incentives are presumed to be misaligned (Langlois, 2006). Opportunistic transaction costs make the incomplete contract approach 'crisp' and 'elegant' and appear to be useful in the investigation of: a) inter-firm arrangements, including those categorized as 'hybrids' (Williamson, 1985, 1991); b) the use of credible commitments and threats (hostages) to support transactions (Williamson 1983); c) finance decisions (Williamson, 1988; Hart \& Moore, 1989; Aghion \& Bolton, 1992; Hart 1995); and, d) property rights Hart \& Moore, 1990; Grossman \& Hart, 1990; Foss \& Foss, 2005).

It is now well established that firms are replete with relational contracts (Gibbons \& Henderson, 2011) and that the existence of these contracts allow the parties to adjust their performances when unexpected events occur (Campbell, 2001). Many of these contracts are 'self-enforcing' performance-based agreements between contracting parties which create a "collaboration sustained by the shadow of the future, as opposed to formal contracts enforced by courts” (Gibbons \& Henderson, 2011, p.1).

Often contracting parties see the contract as a starting point for re-negotiation and adjustment when circumstances change or difficulties arise rather than as carefully defined list of fixed obligations to perform. Therefore, Macneil (1974, 1975, 1980, 1983) considers the 'true or real consent' of contracting parties to be subjective (Barnett, 1992b, p. 1180). Macneil was following Macaulay (1963, 2004) who differentiates between the 'paper deal' and the 'real deal' and observes that firms in practice do not always insist on their contractual rights and do not readily consider the option of litigation. In fact, firms frequently show a willingness to adjust their positions in order to continue to perform (Macaulay, 2004). 
A number of studies approached relational contracting as a governance mechanism (Williamson, 1985, 1991, 2008; Leblebici \& Shalley, 1996; Poppo \& Zenger, 2002) that involves long-term highly specific investments (Ring \& Van de Ven, 1992); fosters inter-firm trust (Das \& Teng, 1999, 2000; Mouzas, Henneberg \& Naudé, 2007; Zaheer \& Venkatraman, 1995); and, minimizes the risk of opportunistic performance (Carson et al., 2006). Incomplete and relational approaches are useful in understanding barriers to anticipating future performance. Nonetheless, to explain how firms attempt to anticipate contractual performance, a theoretical understanding of the ingredients that constitute contractual performance is needed. I posit that performance outcomes of buying and selling solutions for end-users can be assessed as specific combinations of effectiveness, efficiency, and risk (Kotabe, 1998; Mentzer \& Konrad, 1991; Kotler, Jain, \& Maesincee, 2002).

\section{Insert Figure 1 about here}

Contractual effectiveness is about buying and selling solutions that meet endcustomer or end-user needs completely. Contractual effectiveness is thus linked to the firms' ability to design a unique and innovative model of meeting end-user needs through exchange relationships with counterparts (Gaertner \& Ramnarayan, 1983; Mass, 2005). For this reason, effectiveness is inextricably linked with the firms' own recipe to generate a sustainable business growth in their respective markets. Gaertner \& Ramnarayan (1983) argue that effectiveness is not simply a characteristic of contractual outputs but a continuous process relating the firms to their constituencies; in this way, contractual effectiveness is negotiated rather than produced. An effective performance-based contracting is one that is able to create accounts that relevant constituencies find acceptable. These accounts may be for various purposes to various audiences and for various activities. In fast-moving consumer goods industry, for example, manufacturers and retailers jointly create accounts of 'mindspace' measuring 'brand awareness' among consumers; accounts of 'consumer off-takes' measuring final sales to end-consumers at the point of sale; as well as accounts of 'shelf-space' measuring shelf available within retail outlets (Corstjens et al., 1995). Both manufacturers and retailers negotiate with each other in continuing exchange 
relationships, and they manifest their consent for a recurrent performances aimed at end-consumers (Villas-Boas \& Zhao, 2005; Hingley, 2005; Mouzas \& Ford, 2003, 2006; Collins, 2009; Ford \& Mouzas, 2013). Hence, relevant performance-based accounts are not restricted to buying or selling products and services. For example, globally operating retailers, such as Metro, Aldi, or Wal-Mart, for example, shows how retailers are highly effective in financing their business growth by contracting with manufacturers and using them as creditors to provide working capital for their stores.

Contractual efficiency refers to performance outcomes which result in competitive operating margins. Contractual efficiency is thus a measure of operational excellence or productivity. Therefore, contractual efficiency is linked with the firms' ability to provide comprehensive solutions for end-users (Davies, 2004; Essig, 2003; Roehrich \& Caldwell, 2012; Windahl, et al., 2004; Windahl \& Lakemond, 2006, 2010) at a competitive prices and delivering them with minimum difficulty or inconvenience. Contractual efficiency is concerned with minimizing costs and improving operational margins. In theory, efficiency is a necessary condition or hurdle because it is about generating a contractual surplus above the opportunity cost; it could be formulated as a relative number that has profit as a numerator and sales revenue as denominator (Clark, 1921; Mouzas, 2006; Moran and Ghoshal, 1999). In practice, however, business actors cannot easily contract to buy or sell future performances for less than they are worth. Any attempt to explain superior efficiency must account for why business actors were able to acquire this contractual performance supporting such efficiency for a price below their rent generating capacity (Barney, 1986). In their attempt to explain superior efficiency, Denrell et al., (2003) elaborate their analysis on the empirical observation that such efficiency exists whenever prices fail to reflect the value of a resource's best use. This is for example the case when resources are complex and tailor-made or when they comprise not only tangible assets, such as technologies, buildings or inventories, but also intangibles such as 'market-based' and ‘knowledge-based’ resources (Srivastava et al., 1998; Mouzas \& Ford, 2012).

As contracting parties need to expect future performance, one could posit that conceptually between expectations and risks exists a corresponding symmetry. Whilst risks are assigned probabilities to future performances, expectations are "the result of 
drawing inferences from the available data” (Cyert \& March, 1992, p. 163). These inferences might relate to specific contractual outcomes, relationships or business opportunities.

Contractual risk refers to the probability that the occurrence of an event has an adverse impact on the performance of a contract multiplied by the size of material damage or economic loss. In this way, risk exposure appears highly relevant in assessing future performance. Risk exposure is particularly relevant in performancebased contracting because risks are transferred to suppliers and buyers rely on highpowered incentives that are given to their suppliers. The assets that firms utilize are not free of charge. Assets bear an opportunity cost of capital (Modigliani \& Miller, 1958). This is the cost of not contracting in other business opportunities of similar systematic risk. Therefore, the opportunity cost of capital varies from contract to contract, depending on risk that it involves. In practice, firms classify their contracts with similar risks, and calculate the net present value of their expected future revenues and costs. Notwithstanding that risk is passed on to suppliers, performance-based contracting is not an autonomous process; instead performance-based contracting is embedded in a spatiotemporal context. As firms operate in interconnected business relationships, contractual risks are transmitted from one contract to the next; and the adverse impact on firms may be amplified even if risks originate from seemingly distant relationships (Sharpe, 1990; Mouzas \& Ford, 2011; Stulz, 2009). Recent events, such as the credit crisis, the outbreak of food bacteria or the horsemeat fraud in the food industry demonstrate the profound interconnectivity of contracts and raise questions about how firms attempt to deal with risk in their contracting with others (Schwartz and Scott, 2015). Information asymmetry (Nayyar, 1990) and symmetric ignorance imply massively imperfect markets (Akerlof, 1970; Dierickx \& Cool, 1989; Stiglitz, 1993; Harris \& Raviv, 1996) where risk is not equally visible to all firms.

\section{Research Methods}

The research was conducted between September 2010 and March 2013 in the context of long-term supply relationships between multinational firms in Germany and the United Kingdom. The investigated supply relationships involved manufacturers of consumer and pharmaceutical products (A, B), grocery retail chains (C, D) and 
logistics service providers (E, F). The research attention was focused on eight longterm supply relationships ( $\mathrm{AC}, \mathrm{AD}, \mathrm{BC}, \mathrm{BD}, \mathrm{AE}, \mathrm{AF}, \mathrm{BE}, \mathrm{BF}$ ) between manufacturers, retailers, and service providers (see Figure 2). These supply relationships were chosen for investigation for two reasons: First, the contracting between these firms is not concerned with buying or selling certain quantities of consumer products or services at agreed prices; instead, firms' contracting is concerned with buying and selling business performances. Second, the investigated supply relationships form a significant part of the economy; being part of the largest manufacturer-retailer supply chains in Europe and generating an annual turnover of $€ 200$ billion.

A realist epistemological stance guided empirical research endeavors (Sayer, 2000; Tsang \& Kwan, 1999). Using case study research methods (Dubois \& Gadde, 2002; Yin, 2003; Eisenhardt \& Graebner, 2007; Gibbert, Ruigrok \& Wicki, 2008), where case descriptions form the basis for deeper going analysis, I used theoretical tools to move from surface level of description to deeper levels of explanation (Pettigrew, 1990; Pentland, 1999); thus rigorously explain cause-and-effect links of the phenomena that I observed (Tsoukas, 1989; Elster, 1989; Hedstrom \& Swedberg, 1998).

Data Collection: When the research was initiated in September 2010, it became clear that I needed to engage in a longitudinal data collection to capture inter-firm exchanges in their temporal and spatial context (Pettigrew et al., 2001); and simultaneously overcome the initial reluctance of firms to reveal sensitive information about their contractual agreements. For this reason, I initiated an incremental multistage data collection.

In the first stage of the research, which took place between September 2010 and March 2011, I engaged with eight key informants such as Board Members, Heads of Business Units, and Country Managers in the United Kingdom and Germany. The purpose of this initial stage of business engagement was to gain access to multinational firms; identify additional expert interviewees; and develop insights into the history and characteristics of relevant resources and negotiation processes. In 
addition, publicly available information in the form of 241 press releases and 32 annual reports were collected representing a total of compilation of 864 pages.

In the second stage of the research, carried out between April 2011 and March 2013, the pool of key informants was expanded from 8 to 83 decision makers. Interviewees included Corporate Lawyers, Sales Directors, Marketing Directors, Key Account Managers, Category Managers, Purchasing Managers, Financial Managers, Controllers, Auditors and Logistics Specialists. The pool of interviewees includes also two final semi-structured interviews with two independent auditing firms in the United Kingdom and Germany. I chose the auditing firms because they were experts in performance assessment and contracts. The purpose of these two final interviews was to discuss the financial and legal implications, in general; and legal enforceability of inter-firm contracts, in particular. Each interview was face-to-face in the native language of the interviewee and lasted about 45 minutes. The purpose of executing a second stage of data collection was to obtain copies of contracts and engage with the actors that are involved with the design and negotiation of performance-based contract clauses. Obtaining contemporary contracts was a novel method to move beyond subjective views obtained through interviews and examine objectified records and manifestations of consent between firms. Furthermore, the second stage of data collection placed emphasis on obtaining organizational procedures, archival records, reports prepared for key accounts, e-mails as well as protocols of the investigated firms, including two law firms. Implementing a data collection based on multiple sources of evidence was indispensable in the effort to explain how firms deal with barriers to a complete performance-based contract.

Field observations were typed and logged shortly after they occurred into a selfdevised field tracking system. Field observations were classified, catalogued and entered into a "chronological events list" and served as a filter or index to the wider set of observations. This was crucial in the collection of primary data because it helped us carry out a closer examination and triangulation of the data and allowed us to examine the prior and current context of inter-firm contracts. I was also making periodic entries into a field diary to supplement the more formal material gathered about inter-firm agreements. These diary entries provided reflections on the research as a whole. 
Data Analysis: From March 2013 to June 2013, I moved from data collection to data analysis. This involved a critical examination, evaluation, re-categorization and recombination of findings to identify the mechanisms that govern a performancebased contracting. Classifying the empirical evidence, I reconstructed a graphical representation (see Figure 2) of eight supply relationships and captured the chronology and manifestations of involved contractual consent.

\section{Insert Figure 2 about here}

Counterparts' consent to performance targets was classified in three categories: 1) geographical performance targets, 2) monetary performance targets and 3) informational monetary targets. This classification enabled us to report the complexity of empirical results and consider the temporal and spatial context (Pettigrew et al., 2001).

Although the identification of performance targets emerged from the data, our explanations did not emerge directly from the empirical data. For example, the conceptual framework (see Figure 1) which considers contractual performance as combinations of 1) contractual effectiveness, 2) contractual efficiency and 3) contractual risk was a product of identifying relevant knowledge gaps in the literature and confronting theoretical ideas with empirical observations. I found it intriguing that the literature on inter-firm contracting is focused on barriers to anticipating future performance which are considered intractable, such as trust and moral hazard in relationships or transactions costs that impede counterparts' ability to anticipate future performance, without discussing the various ways of how firms deal with these barriers on the basis of a framework of agreed performance targets.

I was motivated to address the research gap and posit conceptual tools that would help us make sense of what constitutes contractual performance. The process of data analysis involved several systematic cycles, whereby, I moved between theoretical 
conceptualizations of performance outcomes and empirical evidence of consent to performance targets. This interplay between theoretical tools and empirical data differs from one-way deductive or inductive methods. In our analysis, the observed world of performance-based contracting was an open system in which events did not invariably follow a determined pattern; instead they were subject to the operation of mechanisms (Tsoukas, 1989; Elster, 1989; Hedstrom \& Swedberg, 1998). For this reason, I needed to engage in rigorous analytical experimentation. This effort encountered three major challenges, namely, the problems of contractual complexity, time, and comparison. Performance-based contracts are often exceedingly long because they incorporate a variety of contract clauses on related to performance targets, economic incentives, notification requirements and risks and liabilities; they are individualized agreements that are updated through annual trade negotiations. For this reason, I focused our research endeavors on eight long-term supply relationships ( $\mathrm{AC}, \mathrm{AD}, \mathrm{BC}, \mathrm{BD}, \mathrm{AE}, \mathrm{AF}, \mathrm{BE}, \mathrm{BF}$ ) between manufacturers, retailers, and service providers and analyzed the agreed performance targets and specific contract clauses to generate reliable comparisons. When I finalized the first draft of the paper, I conducted feedback interviews with three firms from the first stage of data collection to check the validity of observations and interpretations. This feedback proved extremely relevant in fine-tuning our interpretations and testing the internal validity and trustworthiness of our findings.

\section{Empirical Results}

Contextual Setting: The study investigates performance-based contracting in the context of long-term supply relationships in Germany and the United Kingdom. Manufacturers A and B are producers of fast-moving consumer and pharmaceutical goods that built worldwide a reputation for developing brands. Manufacturer A's market capitalization in 2012 was €87 billion and employed worldwide 127,000 fulltime employees. Manufacturer B reported in 2012 a market capitalization of $€ 18$ billion and employed worldwide 51,000 employees. Both manufacturers supply retailer $\mathrm{C}$ and retailer $\mathrm{D}$ which are grocery retail chains focusing on large hypermarkets with an average outlet exceeding 4,000 square meters. In 2012 retailer 
C operated 4600 outlets; employed 84, 500 employees and reported in revenues of $€ 11.5$ billion. In comparison, retailer D operated 9400 outlets and generating $€ 68.7$ billion revenues in 2011. Furthermore, manufacturers A and B collaborate with service provider $\mathrm{E}$ and service provider $\mathrm{F}$ which are logistics companies with expertise in the transportation and storage of food and drinks and well as consumer and pharmaceutical products. In 2012 service Provider E employed 3200 employees and reported revenues of $€ 1.3$ billion while service provider F employed 2800 employees and reported revenues of $€ 1.6$ billion.

Germany and the United Kingdom are the two largest markets in Europe representing a total population of 81 and 62 million consumers respectively (statistical data for 2012). Multinational manufacturers of consumer and pharmaceutical products have expertise in the production, research and development as well as marketing of strong consumer brands in specific product categories, such as food and drink, laundry, cleaning and medical and pharmaceutical products, while grocery retailers, with their resource base defined by the large number of supermarkets and hypermarkets located in certain geographic areas, reach directly and regularly 143 million consumers. These consumers are not merely the final stage of the supply chain; their buying behavior, which is influenced by a multiplicity of socio-economic and cultural trends, provides the primary base of recurrent exchanges between manufacturers and retailers. Logistics service providers provide manufacturers and retailers with distribution and storage services. They are experts in supply chain management and provide services to multiple manufacturers and retailers.

Continuing Relationships: Continuing, long-term supply relationships AC, AD, BC, $\mathrm{BD}, \mathrm{AE}, \mathrm{AF}, \mathrm{BE}, \mathrm{BF}$ are marked by recurrent transactions. Recurrent transactions mean repeated transactions over time, in the sense of repeated buying and selling. Figure 3 demonstrates this. The lowest average number of transactions per annum in the period 2011-2012 was between Manufacturer B and Retailer D (86 transactions); the highest average number of transactions per annum in the same period was between Manufacturer A and Service Provider E. There was evidence that the average number of transactions per annum between manufacturers and service providers (AE, AF, BE, BF) was significantly higher, varying between 248 and 352 transactions per 
annum. The reason for this difference is that service providers were logistic firms that facilitated the storage and transportation of manufacturers' products to multiple customers, such as other retailers, petrol stations and wholesalers. In comparison, the transactions between manufacturers and retailers (AC, AD, BC, BD) were customerspecific transactions varying between 86 and 116 exchanges per annum.

\section{Insert Figure 3 about here}

Continuing relationships necessitate a domain consensus between counterparts over functions and roles in the supply chain. Domains, however, may be disputed and redefined over time. It is, therefore, necessary to look at the firms' boundary conditions and property rights. Manufacturers A and B are not simply producers of consumer and pharmaceutical products; they are also involved in research and development; they own patents and the property rights of brands. Nonetheless, manufacturers A and B need to engage with a relatively small number of major retailers such as retailers $\mathrm{C}$ and $\mathrm{D}$ to negotiate and agree performance target regarding the listing for their brands, private labels, shelf space, trade allowances and promotional support at retailers' outlets. Furthermore, manufacturers A and B need the assets and logistics expertise of service providers $\mathrm{E}$ and $\mathrm{F}$ in the transportation and storage of sensitive consumer and pharmaceutical products.

The service providers' role is to facilitate cost-efficient and well-timed deliveries from manufacturers to retailers. In comparison, retail chains $C$ and $D$ are involved in a direct contact with consumers; thus retailers are concerned with the competitiveness of their outlets and the development of a distinct image among consumers. Regular rounds of price increases to improve operating margins, usually at the start of a calendar year, create significant friction between manufacturers and retailers. Leading manufacturers in each product category will usually initiate a price increase, which will often be followed by other manufacturers of similar branded products. Manufacturers A and B announce wholesale price increases by issuing a new or revised price list. In turn, retailers' interest is to ensure every-day low prices to address customer needs for value products. 
Retailers C and D are very concerned with the increasing cost of goods bought from manufacturers because they have to pass on the higher prices to consumers. This prompts retailers C and D to introduce 'variable pricing' in which final consumer prices change continuously in accordance to value-use and generated savings; and encourages them to launch their own private labels produced by third-party manufacturers.

Contracting Process: Contracting parties meet regularly in periodic and quarterly business reviews in which contractual performance is assessed on an on-going basis. The assessment of performance is feeding back to institutionalized rituals of annual trade negotiations in which performance-based contracts are agreed, re-confirmed or updated. This process allows informed consent, enhanced certainty and calculability of contractual performance and reduces the potential of opportunistic behavior.

Specifically, in the annual trade negotiations that take place between September and December, service providers' managers contact manufacturers' logistics managers. Similarly, the manufacturers' key account managers contact retailers' purchasing managers to review the annual performance of their business relationship. In principle, counterparts $\mathrm{AC}, \mathrm{AD}, \mathrm{BC}, \mathrm{BD}, \mathrm{AE}, \mathrm{AF}, \mathrm{BE}, \mathrm{BF}$ are driven by their wish to maintain and improve their existing relationship. Counterparts recognize the value of their long-term supply relationships and acknowledge their determination to identify new, innovative ways to combine scarce resources to create joint gains. In practice, however, the whole contracting process is driven by: 1) the counterparts' specific interests, for example, considerations of property rights to private labels or brands, exclusivity or liability issues or trade allowances that function as compensation for bearing risks; 2) the actual performance of repeated transactions, as manifested and monitored through information systems, such Electronic Data Interchange, Continuous Stock Replenishment or Vendor Managed Inventory as well as third parties market auditing, such as AC Nielsen and GfK; 3) the recurrent business interactions, for example, periodic business reviews, quarterly business reviews, and task reviews as well as annual negotiations in which contracts are updated on a rolling basis. Hence, service providers D and E, manufacturers A and B and retailers C and D need to negotiate with each other and reach consensus. Manufacturers may propose to 
retailers a number of specific performance targets regarding: a) shelf space and b) promotional space and c) new product launches. For retailers, providing distribution and promotion space for existing and particularly for new product launches (which retailers call 'listing' of new products) represents a considerable risk and incremental 'handing', 'administrative' and 'promotion' cost as well as incremental working capital requirements. For this reason, retailers demand 'trade allowances' which is a fee or payment that acts as a compensation for bearing risks in the supply chain.

Moreover, the retailers demand compensation for bearing the risk of uncertain consumer off-takes. Therefore, retailers demand increasingly high 'trade allowances' as compensation for listing new products, weak brands or proving resource-intensive trade promotions. Retailers' purchasing managers might confront manufacturers' key account managers with performance targets regarding the share of private labels in the product portfolio. Strong manufacturers may reject performance targets on private labels seeing this as a highly risky business policy it creates an asymmetric dependence on retail chains. Weaker manufacturers, however, are more likely to agree these performance targets and produce private labels because they hope to generate incremental sales volume without having to run expensive advertising campaigns. Retailers incentivize performance targets in private labels by waiving the requirement of trade allowances in return for obtaining all property rights to private labels.

In each product category the leading manufacturer is appointed category captain by the retailer. Category captain serve as 'best-practice' firms and thus define the standards versus under-performers. Category captain (best-practice) firms enjoy the privilege of a more intensive collaboration or 'partnership' (as they call it) in category management, merchandising, shelf design projects. Underperforming firms are confronted by their counterparts' with revised performance targets regarding, service level, net-net prices and operating margins as well as product/service portfolio. For example, under-performing manufacturers are confronted by retailers with performance targets regarding private labels.

Performance Targets: Contracting parties negotiated and agreed upon physical, monetary, and informational performance targets. Reaching consent to performance targets in supply relationships (see Table 1: Performance Targets) required 
negotiations that mobilized an extensive integration between demand and supply forces. Negotiations of performance targets were challenging and prolonged over a period of several months because of counterparts' divergent interests and concerns.

In supply relationships between manufacturers and retailers, the manufacturers were concerned with performance targets related to distributional and promotional support at the point that generates consumer demand as well their operating capacities (e.g. volume of shipments), utilization production, research and development of new products, test-markets and product launches. Thus manufacturers needed retailers' consent to performance targets linked with the listing of specified brands or product items, distribution level (numeric distribution targets), shelf availability of their offering, and geographical coverage of retailers' outlets. In contrast, retailers were reluctant to commit themselves to any performance targets regarding the purchasing volume (shipments) from manufacturers and final retail prices. These retailers, however, were willing to accept performance targets regarding number of products and services listed (listing within retail outlets), as well as numerical distribution targets. More importantly, retailers were concerned with performance targets that enabled them variable value-based pricing based on realized level of sell-out performance (consumer off-takes at the point of sale) and obtain trade allowances (which include listing fees, rebates and miscellaneous concessions) consumer offtakes at the point of sale, competitive purchasing prices (net-net wholesale prices). Retailers were also concerned with performance targets related value-in use, cost savings, out-of-stock risks, and private labels that attract and retain end-customers. Despite divergent interests and concerns, counterparts were able to arrive at a mutual agreement regarding performance targets, incentives related to fulfilling or breaching the agreed performance targets and compensations for bearing some of contractual risks.

For example, manufacturer A agreed with retailers C and D on the following:

1) Physical Performance Targets:

Manufacturer A agreed with retailers C and D the exact numerical distribution in retail outlets (expressed as per cent of product availability in retail outlets), the research and development of new products in selected market segments (specifying all new products in the pipeline), property rights of brands and 
private labels (property rights of brands stay with manufacturer A), as well as the implementation of an inter-firm Electronic Data Interchange (to enable accurate forecasting and a continuous stock replenishment).

2) Monetary Performance Targets:

Manufacturer A agreed to pay retailers C and D a fix amount of trade allowances to compensate retailers for bearing the contractual risk of distributing manufacturers' products with uncertain consumer off-takes. Trade allowances that manufacturer A had to pay were specific to stock keeping units (SKU). The trade allowances of new SKUs with uncertain consumer offtakes were higher, while trade allowances for high-performing SKUs (with proven record of consumer off-takes) were lower. Moreover, manufacturer A agreed with retailers $\mathrm{C}$ and $\mathrm{D}$ a 30 days delay of payment. The delay of payment compensated retailers for the time lag between stock replenishment and consumer off-takes. Moreover, Manufacturer A agreed with retailers on cost savings targets that enhance space profitability. Cost savings targets included specific spending targets on research and development and net-net prices of recently introduced private labels.

3) Informational performance targets:

Informational targets that manufacturer A agreed with retailers referred to Electronic Data Interchange, Continuous Stock Replenishment, Scanner Offtake Data, Shopper-insight, Category Management and Efficient Consumer Response.

In supply relationships between manufacturers and logistics service suppliers, counterparts had joint interest in transferring a large share of responsibility to logistics service providers. Nonetheless, logistics service provider E was concerned with the achievement of a sufficiently high value-in-use and the pay-back period of capitalintensive investments in trucks, technology and systems. Therefore, negotiations between logistics service provider $\mathrm{E}$ and manufacturers $\mathrm{A}$ and $\mathrm{B}$ started with the definition of problems and needs (buying logistics performances that address these needs completely and moved gradually to calculations of value-in-use and investment valuations on the basis on the net present value of anticipated future streams of costs 
and revenues. Logistics service provider $\mathrm{E}$ was able to agree with manufacturers A and B upon 'what was needed' and translate needs into performance targets to be achieved. Counterparts were able to arrive at a mutual agreement regarding performance targets and incentives related to fulfilling or breaching the agreed performance targets. Specifically, logistics service provider E agreed with manufacturers upon 1) physical performance targets regarding the geographical coverage of logistics and warehousing services, cross-docking, distribution targets and delivery times, as well as facilitating technologies and systems, 2) monetary performance targets regarding the value per unit and value-in-use, delays in payments, capital investments in systems and technologies and research spending in new innovative applications that enhance operational efficiencies 3) informational performance targets regarding electronic data interchange, continuous stock replenishment, scanner off-take data and efficiency consumer response. Moreover, logistics service provider agreed with manufacturers upon incremental informational performance targets in category management, because this enabled them to generate synergies within the product category of consumer and pharmaceutical products.

Table 1 shows that performance targets were not restricted to physical and monetary targets but involved complex informational targets, such as electronic data interchange that were strengthening the informational links and reducing information asymmetries among contracting parties. Consider the informational performance targets between manufacturer A and retailer C. Retailer C scanner data are linked with manufacturer A's production and warehousing and a continuous stock replenishment enables counterparts a more precise demand forecasting and the achievement of performance targets related a reduction of out-of-stock situations.

Insert Table 1 about here

Performance-based Contract Clauses: Physical, monetary and informational performance targets had been underpinned by binding performance-based contract clauses (see Table 2). Performance-based contract clauses express a framework of 
legally binding principles and rules that incentivize and compel counterparts to achieve agreed performance targets; and thus enhance the certainty and enforceability of contractual performance. These binding principles and rules emphasize the importance of information flow and notification requirements. For example, manufacturer A agreed with retailer $\mathrm{C}$ a technical clause that "mutual notification is required for all future capital investment and $R \& D$ ' and that an 'electronic data interchange" is established to allow an on-going performance monitoring. Notification requirements for capital investments and $R \& D$ aimed at improving counterparts' the strategic planning process while electronic data interchange aimed at improving the operational efficiency of the continuous stock replenishment.

There is evidence that contract clauses had been used in a variety of ways and this is traced back to the observed diversity of norms and counterparties' values and interests. For example, manufacturer A agreed with retailer D that payment is due in 30 days and that delivery cost is paid by the supplier. Manufacturer B stipulated performance-based clauses with retailers that regulated the "transfer of property rights" and "confidentiality" but was concerned with logistics service providers' 'risks', 'liabilities' and the "obligation to remedy deficiencies applied to services obtained from subcontractors”. Similarly, manufacturer B agreed with logistics service providers that the manufacturer maintains "the right to obtain competitive offers at any time”.

Legally all investigated performance-based contracts were indefinite framework contracts which were re-confirmed and updated annually. Thus, contracting parties had the right to terminate the agreement giving one year's prior notice. A part of performance-based contracts refers to property rights and assurances that that no third person has obtained property rights. This is particularly relevant in two areas: a) intellectual property rights on resources, ideas and art work that affect contractual performance; and, b) control over private labels or manufacturer brands. For example, in supply relationship BD, manufacturer B ensured that no third party has obtained property rights over private labels.

Similarly, the evidence suggests that contract clauses on exclusivity rights and confidentiality are critical for performing the contract. For example, manufacturer B 
agreed with retailer C that "all information exchanged is confidential" and "shall not to be available to third parties without written consent of the other party”. Exclusion or force majeure clauses addressed risks that could occur as a result of contextual contingencies. For example, all investigated contracts included a force majeure clause that parties "bear no liability for damages occurred as a result of war, political unrest, strikes, lockouts, and governmental interventions”. To create an in-built contractual flexibility to embrace innovative business opportunities, contracting parties may insert saving clauses. For example, manufacturer A agreed with retailer B that "unless it is of major importance, invalidity of one or more clauses will not have any effect on the agreement as a whole".

\section{Insert Table 2 about here}

\section{Analysis and Discussion}

The conceptual framework is now used to provide a theoretical structure for the analysis of empirical evidence. In line with the conceptual framework (see Figure 1), I consider contractual performance as specific combinations of contractual effectiveness, contractual efficiency, and contractual risk (Kotabe, 1998; Mentzer \& Konrad, 1991; Kotler, Jain \& Maesincee, 2002; Mouzas, 2006). The framework allows us to move on our analysis to a higher aggregation level and make sense of the empirical evidence of how firms anticipate future performance in long-term supply relationships. Specifically, the conceptual framework (see Figure 1) addresses the theoretical deficiency of what it means performance and allows us to connect the ingredients that constitute contractual performance with the empirical evidence of counterparts' consent to a performance-based contracting.

Although extant research work on barriers to anticipating future performance (Hobbs, 1996; Hobbs and Young, 2000; Cachon \& Lariviere, 2001, 2005; Williamson, 2008) is significant, extant research provides limited insights on the question of how firms attempt to overcome these barriers. The empirical evidence indicates that counterparts 
$\mathrm{AC}, \mathrm{AD}, \mathrm{BC}, \mathrm{BD}, \mathrm{AE}, \mathrm{AF}, \mathrm{BE}, \mathrm{BF}$ were able to overcome some of the barriers to anticipating future performance that existing literature points out (Tirole, 1986; Hart \& Moore, 1989; Maskin \& Tirole, 1999; Brown et al., 2004; Taylor \& Plambeck, 2007; Reuer \& Arino, 2007; Furlotti, 2007) and develop a performance-based contracting on the basis of mutual consent to a) performance targets, b) and incentive mechanisms related to fulfilling or breaching the agreed performance targets.

Contracting parties $\mathrm{AC}, \mathrm{AD}, \mathrm{BC}, \mathrm{BD}, \mathrm{AE}, \mathrm{AF}, \mathrm{BE}, \mathrm{BF}$ were able to cope with the following transaction costs: First, information asymmetries and unforeseen contextual contingencies (Maskin \& Tirole, 1999; Tirole, 2009) have been dealt with the implementation of an electronic data interchange and periodic as well as quarterly business reviews. Second, drafting costs (Williamson, 1979, 2008; Mouzas \& Blois, 2013) were reduced because all transactions occurred under the umbrella of an ongoing performance-based contract. Third, enforcement costs were reduced by the introduction of self-enforcing non-legal sanctions (Bernstein, 1992; Charny, 1990; Scott, 2003), such as delisting of brands or services. Fourth, renegotiation requirements (Segal, 1999; Tirole, 2009) were addressed by institutionalized processes of annual trade negotiations in which contracts were confirmed and updated on a rolling basis.

The agreed contract clauses (see table 3: Analysis of Performance-based Contracting) demonstrate that performance that companies buy and sell can be analyzed as specific combinations of effectiveness, efficiency, and risk. Counterparts deliberately avoided performance targets that are related to volumes or final prices. The evidence suggests that counterparts $\mathrm{AC}, \mathrm{AD}, \mathrm{BC}$ and $\mathrm{BD}$ agreed that volumes and prices will be agreed in the future.

These agreed contract clauses in conjunction with performance targets related to consumer off-takes, brand awareness, consumer penetration and distribution levels verified by 3rd parties, such as GfK and ACNielsen, aimed at enhancing contractual effectiveness to respond to emerging opportunities and enable business growth. On the other hand, the agreed clauses between AC, AD that payment in due in 30 days and delivery cost is paid by the supplier or the agreed clauses with service providers $\mathrm{E}$ and $\mathrm{F}$ that pricing is based on a variable value-based and the specific performance 
targets related Electronic Data Interchange and Continuous Stock Replenishment aimed at controlling operating margins and generating saving thus enhancing contractual efficiency.

\section{Insert Table 3 about here}

There is also evidence of agreed clauses that commit parties to remedy deficiencies applied to services obtained from subcontractors and defined proprietary sanctions. Parties would bear no responsibility and liability for any faults that may have been caused outside their direct domain of action. Such prudential measures aimed at risk hedging against potential but unknown risks and obtaining compensation when there is a breach of contract.

Contractual effectiveness, contractual efficiency and contractual risk are analytical lenses that allow us to identify conflicts and incompatibilities in achieving contractual performance. Although counterparts in relationships AC, AD, BC, BD, AE, AF, BE, BF tried to strike a balance between contractual effectiveness, contractual efficiency and contractual risk, they faced tremendous difficulties in achieving excellence in all performance outcomes. The evidence indicates that retail chains $\mathrm{C}$ and $\mathrm{D}$ and logistics firms $\mathrm{E}$ and $\mathrm{F}$ were obsessed with enhancing contractual efficiency and minimizing risk exposure; they constantly pressed to negotiate value-in-use, counterparts' cost savings, and relentlessly passed on risks to their contracting counterparts. Notwithstanding exceptions, such those evidence in supply relationships $\mathrm{AE}$ and $\mathrm{BE}$, the systematic bias towards efficiency gains and risk hedging prevented retailers from pursuing effectiveness increases through innovation and investments in new systems and initiatives, such as category management, test-markets or product re-launches.

Dealing with efficiency and risk in contract performance and neglecting the effectiveness of contractual arrangements means ignoring the creation of new, innovative sources of value. It appears that the emphasis on efficiency and risk hedging is deeply rooted in managers' assumption that the market will eliminate businesses that operate less efficiently than their competitors (Moran \& Ghoshal, 
1999). Consequently, firms implement activity-based costing (Kaplan \& Cooper, 1998), cost reductions, outsourcing, and put unyielding pressure on their suppliers (Sullivan, 1997; Mouzas \& Naude, 2003; Mouzas \& Araujo, 2000).

While some of the investigated firms neglected the relevance of contractual effectiveness, there is compelling evidence that other firms systematically underestimate the multiplying effect of operating margins; they underestimate contractual efficiency. One British retailer, for example, pursued an aggressive expansion of retail outlets despite declining operating margins. Financial distress emerged and the retailer could not sustain its contractual commitments with manufacturers and logistics service supplier. The pressure to operate with the lowest possible margins appears particularly strong in Germany. German retailers, specifically, sell at 'everyday low price' and thus they put pressure on logistics service providers to generate further savings and manufacturers to enhance efficiency of performance in the delivery of products and services.

The emphasis on low price and slim operating margins may be attributed to the dominance of hard-discounters and the high price-sensitivity among end-users in Germany. As a consequence, retailers, manufacturers and service providers in Germany turn to internationalization to benefit from exports into markets with higher operating margins and utilize their production and service capabilities. Mass (2005) provides an excellent illustration of the challenge of balanced performance. Achieving a marginal increase of sustainable business growth appears to be more difficult than achieving a marginal improvement in operating margin.

This difficulty may explain why business managers often choose the easiest way of improving their contractual efficiency instead of enhancing contractual effectiveness. Performing contractual effectiveness requires innovative combination of resources, experimentation, time and the acceptance of a calculated risk exposure. Prior contractual commitments to perform pre-specified outcomes, however, may limit counterparts' ability to differentiate or change their contractual arrangements in the future (Argyres \& Liebeskind, 1999). The present study confirms that new, innovative sources of value were specific to counterparts $\mathrm{AC}, \mathrm{AD}, \mathrm{BC}, \mathrm{BD}, \mathrm{AE}, \mathrm{AF}, \mathrm{BE}, \mathrm{BF}$ that created them and counterparts are usually specifically prepared for them by their pre- 
history of contractual arrangements. For example, by institutionalizing annual trade negotiations and quarterly business reviews, counterparts $\mathrm{AC}, \mathrm{AD}, \mathrm{BC}, \mathrm{BD}, \mathrm{AE}, \mathrm{AF}$, $\mathrm{BE}, \mathrm{BF}$ were able to enhance their effectiveness in responding to emerging opportunities in the business landscape and flexibly update their pre-existing agreements. Similarly, the agreement to implement a continuous stock replenishment acted as an early warning system to alert counterparts about imminent problems. Extant research (Ring and Van de Ven, 1992; Das \& Teng, 1999; Das \& Teng, 2000; Hagedoorn \& Hesen, 2007; Reuer \& Arino, 2003, 2007) points out long-term supply relationships enable counterparts to put greater effort into contingency planning in performance targets, which is consistent with learning effects over time (Argyres et al., 2007; Mayer \& Argyres, 2004). In this way, long-term supply relationships appear to be conducive to a performance-based contracting.

\section{Conclusion and Implications}

The study has demonstrated that firms in long-term supply relationships are able to overcome barriers to anticipating future performance and develop a performancebased contracting. Firms are able to negotiate and agree upon performance targets and underpin these targets with specific contract clauses that incentivize and compel counterparts to achieve agreed performance targets. Performance-based contracting in long term supply relationships enables counterparts to implement variable valuebased pricing based on realized level of performance, such incremental revenues, consumer off-takes, cost savings; and simultaneously obtain compensation in the form of trade allowances for bearing contractual risks.

Performance-based contracts in long-term supply relationships draw our attention to two intriguing aspects. Firstly, relational and implicit norms embedded in customs and practices in supply chains are transformed into explicit performance targets and contract clauses. Thus, performance-based contracts introduce shared values and give a sense of purpose; they codify the parties' knowledge about a) effective, b) efficient and c) prudent ways to buy solutions to business problems; and, hence, become “knowledge repositories” (Mayer \& Argyres, 2004, p. 405) and reference points (Hart \& Moore, 2008). The evidence that the primary concern of performance-based 
contracting is with sharing knowledge between contracting parties is supported by studies of strategic alliance contracts (Taylor \& Plambeck, 2007; Reuer \& Arino, 2007). These studies demonstrate that sharing knowledge among firms deepens interpartner communication and lead to a tacit development of contractual provisions for troubleshooting. Secondly, the function of performance-based contracting is not to predetermine contractual decisions but to provide a framework (Weber \& Mayer, 2011) within which expectations and contractual decisions conducive to performance can be made. This functional particularity is crucial for understanding how firms engage in a performance-based contracting with each other. Scholarly work on contracts has obscured the difference between contractual decisions and the performance framework where contractual decisions are made. The above functional differentiation is critical in advancing our theory on how companies overcome barriers to anticipating future performance to arrive at a genuine consent to performance targets.

Empirical evidence and theory suggests that, absent genuine consent (Barnett, 1986; Barnett, 2002), contractual arrangements are not sustainable because they do not facilitate the creation of the maximum potential value (Kronman \& Posner, 1979; Sebenius, 1992). This is apparent in the frequent instabilities of those business partnerships and contractual arrangements which fail to manage tensions such as “cooperation versus competition, rigidity versus flexibility or short-term versus longterm orientation" (Das \& Teng, 2000, p.94). Instabilities are evident in the engagement of retailers in private labels, as private labels can be regarded as a deliberate attempt by grocery retailers to invade domains that are traditionally the preserve of consumer goods manufacturers (Dunne \& Narasimhan, 1999; Narasimhan \& Wilcox, 1998).

Contracting parties consent to a framework of performance targets because they derive benefits from 'framing' the whole contracting process according to a set of objectified end-results. Performance-based contracting: a) reduces the costs of running recurrent transactions; b) provides certainty and calculability regarding the conditions under which performance may take place; and, c) reduces information asymmetry by providing a platform for continuing assessment of contractual performance. 


\section{Managerial Implications}

Business Managers and management teams involved in business procurement could carry, champion, and mediate the following guiding principles in designing and negotiating a performance-based contracting:

Foster a shared understanding of what constitutes performance: Fostering a shared understanding of performance requires a continuous effort to 1) define performance targets and 2) monitor specific performance. Procurement Managers should not take a 'shared understanding' of performance for granted. A practical way to approach this challenge is to consider performance-based contracting as 'work-inprogress' or recurrent practice of setting performance targets from an end-user perspective and then institutionalizing a process of monitoring performance targets through recurrent business interactions, such as negotiation episodes, periodic or quarterly business reviews.

Link performance targets with explicit contract clauses: Business managers involved in the procurement need to be aware that performance targets need to be complemented by legally enforceable contract clauses that guide 'shared principles' and 'shared data', so that they can be used practically to govern individual transactions. Electronic data interchange, open-book agreements, framework agreements or memoranda of understandings between the supplier and buyer firm, can facilitate this endeavor. It is critical that 'shared principles' and 'shared data' are supported by explicitly stated, high-powered incentives that energize counterparts to achieve the agreed performance targets.

Achieve a balanced performance-based contracting: It is challenging to achieve a balance between a) effective, b) efficient and c) prudent ways of contracting. Yet to maximize a sustainable return on assets, business managers involved in the procurement need to be aware that performance-based contracting rests on wholeness and coherence. Contractual effectiveness requires different managerial capabilities 
than those needed for dealing with contractual efficiency or for dealing with contractual risk. Effectiveness requires procurement managers to improve their firm's capacity to generate sustainable growth in their supply relationship; efficiency involves discipline and control over operating margins and working capital requirements; and risk necessitates prudence and foresight. To achieve a balanced performance-based contracting in long-term relationships, managers need to develop new applications, such as indefinite framework contracts that require 1) the integration of external potentials and internal capabilities, 2) the synchronization of short-term and long-term performance, 3) the co-existence of co-operation with partners to create value and competition with counterparts to claim value, 4) the harmonization of the general relational norms of practice and the specific contract clauses that incentivize performance, and 5) the symbiosis of the past contracting and the future contracting.

\section{Future Research}

This research outcome could stimulate a research agenda along two themes: First, empirical investigation is needed on how performance-based contracting can contribute to a sustainable business growth. Resources that are market-based (Shrivastava et al., 1990), knowledge-based (Mouzas \& Ford, 2012) or brand-based (Barwise et al., 1990) are recognized as significant in the process of performing sustainable growth. Nonetheless, our knowledge of how firms structure a performance-based contracting that is conducive to a sustainable growth is still limited. Second, more empirical research is needed on performance-based contracting deals with risk exposure. Firms tend to pass on risks to their suppliers; nonetheless, firms are not immune from external risks, even if the risks are diversified away. The recent crisis in financial institutions has demonstrated this (Mouzas \& Ford, 2011). As firms contract within interconnected supply relationships, risks are transmitted from one relationship to the next; and the adverse impact on firms may be amplified, even if risks originate from seemingly distant parts of a supply chain. Dealing with this kind of contractual risk is not about hedging against counterparty's risk; instead, it is about dealing with a potentially indirect counterparty's counterparty risk. The present study hopefully provides a stimulus for the start of this exploration. 


\section{References}

Aghion, P., \& Bolton, P. (1992). An 'Incomplete Contracts' Approach to Financial Contracting. Review of Economic Studies, 59, 473-494.

Akerlof, G. (1970). The market for lemons: Qualitative uncertainty and the market mechanism. Quarterly Journal of Economics, 84(3), 488-501.

Amit, R., \& Schoemaker, P.J.H. (1993). Strategic assets and organizational rent. Strategic Management Journal, 14(1), 33-46.

Anderlini, L., \& Felli, L. (1994). Incomplete Written Contracts. Quarterly Journal of Economics, 109, 1085-1124.

Araujo, L., \& Spring, M. (2010). Complex performance, process modularity and the spatial configuration of production. Procuring Complex Performance: Studies in Innovation in Product-service Management, Routledge, London.

Argyres, N., \& Mayer, K.J. (2007). Contract design as a firm capability: An integration of learning and transaction cost perspectives. Academy of Management Review, 32 (4), 1060-1077.

Argyres, N., Bercovitz, J., \& Mayer, K. J. (2007). Complementarity and evolution of contractual provisions: an empirical study of IT services contracts. Organization Science, 18(1), 3-19.

Argyres, N.S., \& Liebeskind, J.P. (1999). Contractual commitments, bargaining power, and governance inseparability: Incorporating history into transaction cost theory. Academy of Management Review, 24(1), 49-64.

Arrighetti, A., Bachmann, R., \& Deakin, S. (1997). Contract law, social norms and inter-firm cooperation. Cambridge Journal of Economics, 21(2), 171-195.

Atiyah, P.S. (1986). Essays on Contract. Clarendon Press. Oxford University Press: Oxford.

Atiyah, P.S. (1995). An introduction to the law of contract. Clarendon Law: Oxford.

Bajari, P., \& Tadelis, S. (2001). Incentives versus transaction costs: A theory of procurement contracts. RAND Journal of Economics, 387-407.

Baker, G., Gibbons, R., \& Murphy, K.J. (2002). Relational contracts and the theory of the firm. Quarterly Journal of Economics, 117 (1), 39-84. 
Baker, G., Gibbons, R., \& Murphy, K.J. (2008). Strategic alliances: bridges between 'islands of conscious power'. Journal of the Japanese and International Economies, 22(2), 146-163.

Baraldi, E. \& Stromsten, T. (2009). Controlling and Combining Resources in Networks - from Uppsala to Stanford and Back Again: The Case of a Biotech Innovation. Industrial Marketing Management, 38 (5), 541-552.

Barnett, R.E. (1986). A consent theory of contract. Columbia Law Review, 86(2), 269321.

Barnett, R.E. (1992a). The sound of silence: default rules and contractual consent. Virginia Law Review, 78, 829-59.

Barnett, R.E. (1992b). Conflicting visions: A critique of Ian Macneil's relational theory of contract. Virginia Law Review, 78, 1175-1206.

Barnett, R.E. (2002). Consenting to form contracts. Fordham Law Review, 71(3), 627645.

Barney J.B. (1986). Strategic factor markets: expectations, luck, and business strategy. Management Science, 32, 1512-1514.

Barney J.B. (1991). Firm resources and sustained competitive advantage. Journal of Management, 17, 99-120.

Barratt, M. (2004). Understanding the meaning of collaboration in the supply chain. Supply Chain Management: An International Journal, 9(1), 30-42.

Barwise, P., Marsh, R.R., \& Wensley, R. (1989). Must finance and marketing clash? Harvard Business Review, 67(5), 85-91.

Bernstein, L. (1992). Opting out of the legal system: Extralegal contractual relations in the diamond industry. Journal of Legal Studies, 21, 115- 157.

Biggart, N.W., Delbridge, R. (2004). Systems of exchange. Academy of Management Review, 29 (1), 28-49.

Blois, K. (2003). B2B “relationships”: a social construction of reality? A study of Marks and Spencer and one of its major suppliers. Marketing Theory, 3(1), 7995.

Brown, M., Falk, A., \& Fehr, E. (2004). Relational contracts and the nature of market transactions. Econometrica, 72 (3), 747-780.

Buchanan, J.M. (1975). A contractarian paradigm for applying economic theory. American Economic Review, 65 (2), 225-230. 
Cachon, G., \& Lariviere, M. (2001). Turning the supply chain into a revenue chain. Harvard Business Review, (March), 20-21.

Cachon, G.P., \& Lariviere, M.A. (2001). Contracting to assure supply: How to share demand forecasts in a supply chain. Management Science, 47(5), 629-646.

Caldwell, N. D., \& Settle, V. (2011). Incentives and contracting for availability: procuring complex performance. In Complex Engineering Service Systems (pp. 149-162). Springer London.

Caldwell, N.D., Roehrich, J. K., \& Davies, A.C. (2009). Procuring complex performance in construction: London Heathrow Terminal 5 and a Private Finance Initiative hospital. Journal of Purchasing and Supply Management, 15(3), 178-186.

Campbell, D. (2001). Relational Theory of Contract: Selected Works of Ian Macneil. Sweet \& Maxwell: London.

Carson, S.J., \& Madhok, A., \& Wu, T. (2006). Uncertainty, opportunism, and governance: The effects of volatility and ambiguity on formal and relational contracting. Academy of Management Journal, 49 (5), 1058-1077

Charny, D. (1990). Nonlegal sanctions in commercial relationships. Harvard Law Review, 103, 373-467.

Che, Y.K., \& Hausch, D.B. (1999). Cooperative investment and the value of contracting. American Economic Review, 89 (1), 125-147.

Choi, Y.B. (1993). Paradigms and conventions: Uncertainty, decision-making and entrepreneurship. University of Michigan Press: Ann Arbor.

Coase, R. (1960). The Problem of Social Cost. Journal of Law and Economics 3, 144.

Collins, H. (1999). Regulating Contracts. Oxford University Press: Oxford.

Collins, H. (2009). The weakest Link. Legal Implications of the Network Architecture of Supply Chains. In Networks: Legal Issues of Multilateral Co-operation, pp. 187-210, edited by G. Teubner and M. Amstutz, Hart Publications.

Corstjens, J., Corstjens, M., \& Lal, R. (1995). Retail competition in the fast-moving consumer goods industry: the case of France and the UK. European Management Journal, 13(4), 363-373.

Crook, T.R., Ketchen Jr., D.J., Combs, J.G., \& Todd, S.Y. (2008). Strategic resources and performance: A meta-analysis. Strategic Management Journal, 29 (11), 1141-1154. 
Cyert, R.M., \& March, J.G. (1992). A Behavioral Theory of the Firm. 2nd ed. Oxford: Blackwell Business.

Das, T.K., \& Teng, B.S. (1999). Managing Risks in Strategic Alliances. The Academy of Management Executive, 13, 50-62.

Das, T.K., \& Teng, B.S. (2000). Instabilities of Strategic Alliances: An Internal Tensions Perspective. Organization Science, 11, 77-101.

Davies, A. (2004). Moving base into high-value integrated solutions: a value stream approach. Industrial and Corporate Change, 13(5), 727-756.

Denrell, J., Fang, C., \& Winter, S. (2003). The economics of strategic opportunity. Strategic Management Journal, 24, 977-990.

Dierickx, I., \& Cool, K. (1989). Asset stock accumulation and sustainability of competitive advantage. Management Science, 35, 1504-1511.

Dubois, A., \& Gadde, L.E. (2002). Systematic combining: an abductive approach to case research. Journal of Business Research, 55(7), 553- 560.

Dunne, D. C. \& Narasimhan, C. (1999). The New Appeal of Private Labels. Harvard Business Review, 77(3), 41-49.

Eisenhardt, K.M., \& Graebner, M.E. (2007). Theory Building from Cases: Opportunities and Challenges. Academy of Management Journal, 50(1), 2532.

Elster, J. (1989). Nuts and Bolts for the Social Sciences. Cambridge: Cambridge University Press.

Esper, T.L., Ellinger, A., Tank, T.S., Flint, D. \& Moon, M. (2010). “Demand and Supply Integration: A Conceptual Framework of Value Creation Through Knowledge Management," Journal of the Academy of Marketing Science, 38(1), 5-18.

Essig, M. (2000). Purchasing consortia as symbiotic relationships: developing the concept of “consortium sourcing”. European Journal of Purchasing \& Supply Management, 6(1), 13-22.

Essig, M. (2003). Kooperationen in der industriellen Beschaffung. In Kooperationen, Allianzen und Netzwerke (pp. 659-681). Gabler Verlag.

Essig, M., \& Arnold, U. (2001). Electronic procurement in supply chain management: an information economics-based analysis of electronic markets. Journal of Supply Chain Management, 37(3), 43-49. 
Faems, D., Janssens, M., Madhok, A., \& Van Looy, B. (2008). Toward an integrative perspective on alliance governance connecting. Academy of Management Journal, 51(6), 1053-1078.

Fehr, E., Hart, O. \& Zehnder, C. (2011). Contracts as Reference Points-Experimental Evidence. American Economic Review, 101(2), 493-525.

Ford, D. \& Mouzas, S. (2010). Networking under Uncertainty: Concepts and Research Agenda. Industrial Marketing Management, 39 (6), 956-962.

Ford, D., \& Mouzas, S. (2013). Service and Value in the Interactive Business Landscape. Industrial Marketing Management, 42(2), 9-17.

Foss, K., \& Foss, N.J. (2005). Value and transaction costs: How property rights economics furthers the resource-based view. Strategic Management Journal, 26, 541-556.

Furlotti, M. (2007). There is more to contracts than incompleteness: a review and assessment of empirical research on inter-firm contract design. Journal of Managerial Governance, 11, 61-99.

Gaertner GH, \& Ramnarayan, S. (1983). Organizational effectiveness: an alternative perspective. Academy of Management Review, 8(1),97-107

Ghoshal, S., \& Moran, P. (1996). Bad for Practice: A Critique of the Transaction Cost Theory. The Academy of Management Review, 21(1), 13-47.

Gibbert, M., Ruigrok, W., \& Wicki, B. (2008). Research notes and commentaries what passes as a rigorous case study. Strategic Management Journal, 29(13), $1465-1474$.

Gibbons, R. (2005). Four formal(izable) theories of the firm? Journal of Economic Behavior and Organization, 58, 200-245.

Gibbons, R., \& Henderson, R. (2012). Relational Contracts and Organizational Capabilities. Organization Science, 23(5), 1350-1364.

Glas, A., Hofmann, E., \& Essig, M. (2013). Performance-based logistics: a portfolio for contracting military supply. International Journal of Physical Distribution \& Logistics Management, 43(2), 97-115.

Gnyawali, D.R. \& Madhavan, R. (2001). Cooperative networks and competitive dynamics: Structural embeddedness perspective. Academy of Management Review, 26(3), 431-445. 
Grossman, S., \& Hart, O. (1990). The costs and benefits of ownership: A theory of vertical and lateral integration. Journal of Political Economy, 94, 691-719.

Hagedoorn, J., \& Hesen, G. (2007). Contract Law and the Governance of Inter-Firm Technology Partnerships-An Analysis of Different Modes of Partnering and Their Contractual Implications. Journal of Management Studies, 44 (3), 342366.

Harris, M., \& Raviv, A. (1996). The capital budgeting process: Incentives and information. Journal of Finance, 51(4), 1139-1174.

Harrison, D. (2004). Is a Long-term Business Relationship an Implied Contract? Two Views of a Relationship Disengagement. Journal of Management Studies, 41 (1), 107-125.

Hart, O. \& Moore, J. (1989). Default and Renegotiation: A Dynamic Model of Debt, Quarterly Journal of Economics, 113, 1-41, 1998).

Hart, O. (1995). Firms, Contracts, and Financial Structure. Clarendon Press: Oxford.

Hart, O., \& Moore, J. (1990). Property rights and the nature of the firm. Journal of Political Economy, 98, 1119-1158.

Hart, O., \& Moore, J. (2008). Contracts as Reference Points. Quarterly Journal of Economics 123, 1-48.

Hedstrom, P., \& Swedberg, R. (Eds.) (1998). Social Mechanisms. An Analytical Approach to Social Theory. Cambridge, Cambridge University Press.

Heide, J.B., \& John, G. (1990). Alliances in industrial purchasing: The determinants of joint action in buyer-supplier relationships. Journal of Marketing Research, 27(1), 24-36.

Hobbs, J.E. \& Young, L.M. (2000). Closer vertical co-ordination in agrifood management. Supply Chain Management, 1(2), 15-17.

Hobbs, J.E. (1996). A transaction cost approach to supply chain supply chains: A conceptual framework and some preliminary evidence. Supply Chain Management, 5 (3), 131-143.

Klein, B. (1980). Transaction cost determinants of 'unfair' contractual arrangements. American Economic Review, 70(2), 356-362.

Kotabe, M. (1998). Efficiency vs. effectiveness orientation of global sourcing strategy: A comparison of US and Japanese multinational companies. The Academy of Management Executive, 12(4), 107-119. 
Kotler, P., Jain, D., \& Maesincee, S. (2002). Marketing moves: a new approach to profits, growth, and renewal. Harvard Business Press.

Kronman, A.T., \& Posner, R. (1979). The economics of contract law. Little, Brown and Co.: Boston, Mass.

Leblebici, H., \& Shalley, C.E. (1996). The organization of relational contracts: The allocation of rights in franchising. Journal of Business Venturing, 11(5), 403418.

Lepak, D.P., Smith, K.G. \& Taylor, M.S. (2007). Value creation and value capture: A multilevel perspective. Academy of Management Review, 32(1), 180-194.

Levin, J. (2003). Relational incentive contracts. American Economic Review, 93(3), 835-857.

Lewis, M.A., \& Roehrich, J.K. (2009). Contracts, relationships and integration: towards a model of the procurement of complex performance. International Journal of Procurement Management, 2(2), 125-142.

Loasby, B.J. (2000). Market institutions and economic evolution. Journal of Evolutionary Economics, 10(3), 297-309.

Lusch, R.F., \& Brown, J.R. (1996). Interdependency, contracting, and relational behavior in marketing channels. The Journal of Marketing, 19-38.

Macaulay, S. (1963). Non-contractual relationships in business: A preliminary study. American Sociological Review, 28, 55-69.

Macaulay, S. (2004). The real and the paper deal: empirical pictures of relationships, complexity and the urge for transparent simple rules. Modern Law Review, 66, 44-79.

Macneil, I.R. (1974). Restatement (Second) of contracts and presentiation. Virginia Law Review, 60(4), 589-610.

Macneil, I.R. (1975). A primer of contract planning. Southern California Law Review, 48, 627-704.

Macneil, I.R. (1980). The New Social Contract. Yale University Press: New Haven, CT.

Macneil, I.R. (1983). Values in contract: internal and external. Northwestern University Law Review, 78, 340-418.

Macneil, I.R. (1985). Relational contract: What we do and do not know. Wisconsin Law Review, 483-525. 
Macneil, I.R. (2000). Relational contract theory: challenges and queries. Northwestern University Law Review, 94, 877-907.

Maskin, E., \& Tirole, J. (1999). Unforeseen contingencies and incomplete contracts. The Review of Economic Studies, 66(1), 83-114.

Mayer, K.J., \& Argyres, N. (2004). Learning to contract: evidence from the personal computer industry. Organization Science, 15(4), 394-410.

McKendrick, E. (2002). The Regulation of Long-term Contracts in English law. In Good Faith and Fault in Contract Law, Beatson J, Friedmann D. (eds). Clarendon Press: Oxford; 306-333.

Mentzer, J.T., \& Konrad, B.P. (1991). An efficiency/effectiveness approach to logistics performance analysis. Journal of business logistics, 12(1), 33-62.

Modigliani, F., \& Miller, M.H. (1958). The cost of capital, corporation finance and the theory of investment. American Economic Review, 48, 261-297.

Mouzas, S. \& Ford, D. (2011). Herd Behaviour in Business Networks. Die Betriebswirtschaft, - Business Administration Review (BARev)-, Heft 6/2011.

Mouzas, S. (2006). Efficiency versus effectiveness in business networks. Journal of Business Research, 59(10), 1124-1132.

Mouzas, S. (2006). Negotiating Umbrella Agreements. Negotiation Journal, 22 (3), 279-302.

Mouzas, S., \& Araujo, L. (2000). Implementing programmatic initiatives in manufacturer-retailer networks. Industrial Marketing Management, 29(4), 293-303.

Mouzas, S., \& Blois, K. (2013). Contract research today: Where do we stand?. Industrial Marketing Management, 42(7), 1057-1062.

Mouzas, S., \& Ford, D. (2003). Negotiating in Networks: Unleashing the Power of Options. Journal of Customer Behaviour, 2, 2-20.

Mouzas, S., \& Ford, D. (2006). Managing relationships in showery weather: The role of umbrella agreements. Journal of Business Research, 59, 1248-1256.

Mouzas, S., \& Ford, D. (2012) Leveraging knowledge based resources: the role of contracts. Journal of Business Research, 65 (2), 153-161.

Mouzas, S., Henneberg, S., \& Naudé, P. (2007). Trust and reliance in business relationships. European Journal of Marketing, 41(9/10), 1016-1032

Myers, S. (1999). Finance Theory and financial strategy. In D. H. Chew, Jr. (Ed.), The New Corporate Finance: Irwin McGraw-Hill. 
Narasimhan, C., \& Wilcox, R.T. (1998). Private Labels and the Channel Relationship: A Cross-Category Analysis. Journal of Business, 71(4), 573-600.

Nayyar, P.R. (1990). Information asymmetries: A source of competitive advantage for diversified service firms. Strategic Management Journal, 11(7), 513-519.

Nee, V. (1998). Norms and networks in economic and organizational performance. American Economic Review, 88(2), 85-89.

Pentland, B.T. (1999). Building process theory with narrative: From description to explanation. Academy of Management Review, 24, 711-724.

Pettigrew, A.M. (1990). Longitudinal field research on change: Theory and practice. Organization Science, 1, 267-292.

Pettigrew, A.M., Woodman, R.W., \& Cameron, K.S. (2001). Studying Organizational Change and Development: Challenges for Future Research. Academy of Management Journal, 44(4), 697-713.

Poppo, L., \& Zenger, T. (2002). Do formal contracts and relational governance function as substitutes or complements? Strategic Management Journal, 23, 707-725.

Pratt, M.G. (2009). From the editors: For the lack of a boilerplate: Tips on writing up (and reviewing) qualitative research. Academy of Management Journal 52(5): 856-862.

Reuer, J.J., \& Arino, A. (2003). Strategic alliances as contractual forms. Academy of Management Best Paper Proceedings.

Reuer, J.J., \& Arino, A. (2007). Strategic alliance contracts: Dimensions and determinants of contractual provision. Strategic Management Journal, 28, 313-330.

Ring, P.S., \& Van de Ven, A.H. (1992). Structuring Cooperative Relationships between Organizations. Strategic Management Journal, 13, 483-498.

Roehrich, J. K., Lewis, M.A., \& George, G. (2014). Are public-private partnerships a healthy option? A systematic literature review. Social science \& Medicine, 113, 110-119.

Roehrich, J., \& Lewis, M. (2014). Procuring complex performance: implications for exchange governance complexity. International Journal of Operations \& Production Management, 34(2), 221-241. 
Roehrich, J.K., \& Caldwell, N.D. (2012). Delivering integrated solutions in the public sector: The unbundling paradox. Industrial Marketing Management, 41(6), 995-1007.

Roehrich, J.K., Caldwell, N.D., \& Lewis, M. A. (2014). Procuring Complex Performance (PCP) in the UK Defence Sector. In Performance Based Logistics (pp. 109-125). Springer Fachmedien Wiesbaden.

Roxenhall, T., \& Ghauri, P. (2004). The Use of written contract in long-lasting business relationships. Industrial Marketing Management, 33(3), 261-268.

Schwartz, A. \& Scott, R.E. (2015). Third-Party Beneficiaries and Contractual Networks. Journal of Legal Analysis, First published online July 23, 2015, doi:10.1093/jla/lav006

Schwartz, A. (1992). Relational contracts in courts: An analysis of incomplete agreements and judicial strategies. Journal of Legal Studies, 21(2), 271-318.

Scott, R.E. (2003). A Theory of Self-Enforcing Indefinite Agreements. Columbia Law Review, 103 (7), 1641-1699.

Sebenius, J.K. (1992). Negotiation analysis: A characterization and review. Management Science, 38(3), 18-38.

Segal, I. (1999). Complexity and Renegotiation: A Foundation for Incomplete Contracts. Review of Economic Studies, 66, 57-82.

Selviaridis, K., \& Spring, M. (2010). The dynamics of business service exchanges: insights from logistics outsourcing. Journal of Purchasing and Supply Management, 16(3), 171-184.

Sharpe, S.A. (1990). Asymmetric Information, Bank Lending and Implicit Contracts:

A Stylized Model of Customer Relationships. Journal of Finance, 45(4), 1069-1087.

Spekman, R.E., Kamauff , Jr J.W., \& Myhr, N. (1998). An empirical investigation into supply chain management: a perspective on partnerships. Supply Chain Management, 3(2), 53-67.

Srivastava R.K., Shervani T.A., \& Fahey L. (1998). Market-based assets and shareholder value: a framework for analysis. Journal of Marketing, 62, 2-18.

Srivastava, R.K., Shervani, T.A., \& Fahey, L. (1998). Market-based assets and shareholder value: A framework for analysis. The Journal of Marketing, 2-18.

Stiglitz, J.E. (1988). Why financial structure matters. Journal of Economic Perspectives, 2, 121-126. 
Stulz, R. M. (2009). Six Ways to Mismanage Risk. Harvard Business Review, 3(3), 86-94.

Sullivan, M.W. (1997). Slotting allowances and the market for new products. Journal of Law and Economics, 40(2), 461-493.

Taylor, T.A., \& Plambeck, E. (2007). Supply chain relationships and contracts: The impact of repeated interaction on capacity investment and procurement. Management Science, 53(10), 1577-1593.

Tirole, J. (1999). Incomplete contracts: Where do we stand? Econometrica, 67(4), 741-781.

Tirole, J. (2009). Cognition and Incomplete Contracts. American Economic Review, 99, 265-294.

Tsang, E., \& Kwan, K.M. (1999). Replication and Theory Development in Organizational Science: A Critical Realist Perspective. The Academy of Management Review, 24(4), 759-780.

Tsoukas, H. (1989). The Validity of Idiographic Research Explanations. Academy of Management Review, 14(4), 551-561.

Villas-Boas, J.M., \& Zhao, Y. (2005). Retailers, manufacturers, and individual consumers: Modeling the supply side in the ketchup marketplace. Journal of Marketing Research, 42(1), 83-95.

Weber, L., \& Mayer, K. (2011). Designing Effective Contracts: Exploring the the Influence of Framing and Expectations. Academy of Management Review, 36(1), 53-75.

Williamson, O.E. (1979). Transaction-Cost Economics: The Governance of Contractual Relations. Journal of Law and Economics, 22(2), 233-261

Williamson, O.E. (1983). Credible commitments: Using hostages to support exchange. American Economic Review, 73, 519-540.

Williamson, O.E. (1985). The Economic Institutions of Capitalism. Free Press: New York.

Williamson, O.E. (1988). Corporate Finance and Corporate Governance. Journal of Finance, 43, 567-591.

Williamson, O.E. (1991). Comparative Economic Organization. Administrative Science Quarterly, 36, 269-296.

Williamson, O.E. (2008). Outsourcing: Transaction Cost Economics and Supply Chain Management. Journal of Supply Chain Management, 44 (2), 5-16. 
Windahl, C., \& Lakemond, N. (2006). Developing integrated solutions: The importance of relationships within the network. Industrial Marketing Management, 35(7), 806-818.

Windahl, C., \& Lakemond, N. (2010). Integrated solutions from a service-centered perspective: Applicability and limitations in the capital goods industry. Industrial Marketing Management, 39(8), 1278-1290.

Windahl, C., Andersson, P., Berggren, C., \& Nehler, C. (2004). Manufacturing firms and integrated solutions: characteristics and implications. European Journal of Innovation Management, 7(3), 218-228.

Yin, R.K. (2003). Case study research: Design and methods (3rd ed.).London: Sage.

Zaheer, A., \& Venkatraman, N. (1995). Relational governance as an interorganisational strategy: an empirical test of the role of trust in economic exchange. Strategic Management Journal, 16, 373-92. 
Figure 1: A Conceptual Framework for the Analysis of Performance

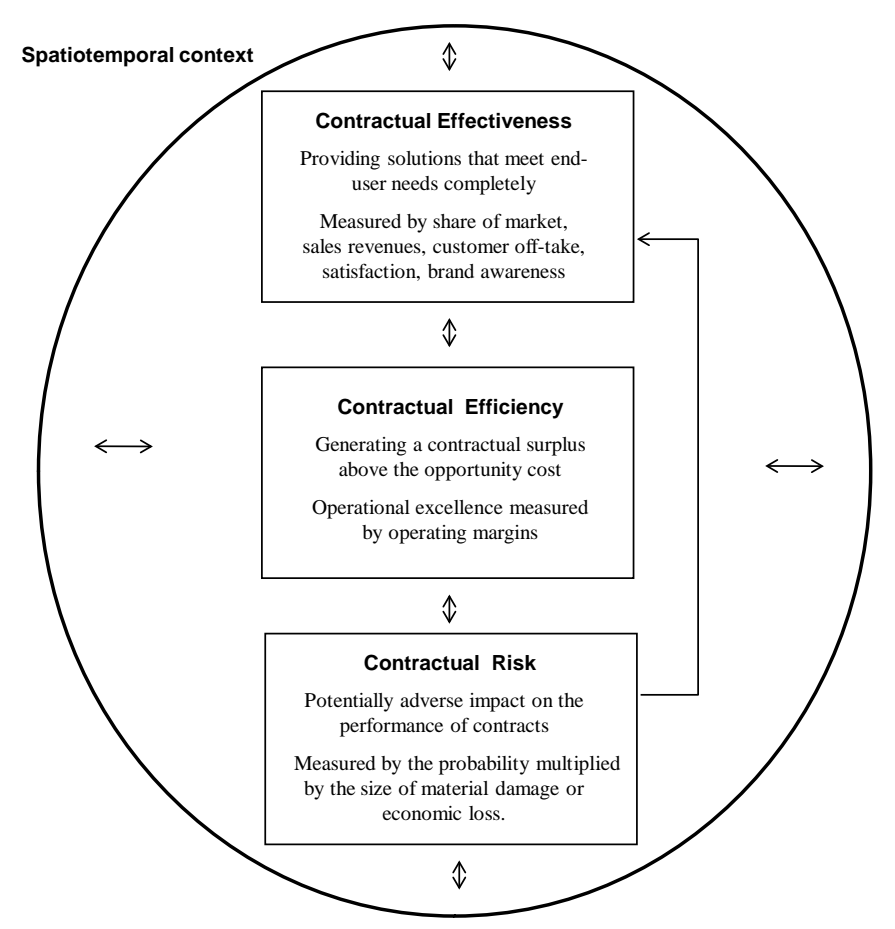


Figure 2: Graphical Representation of Supply Relationships

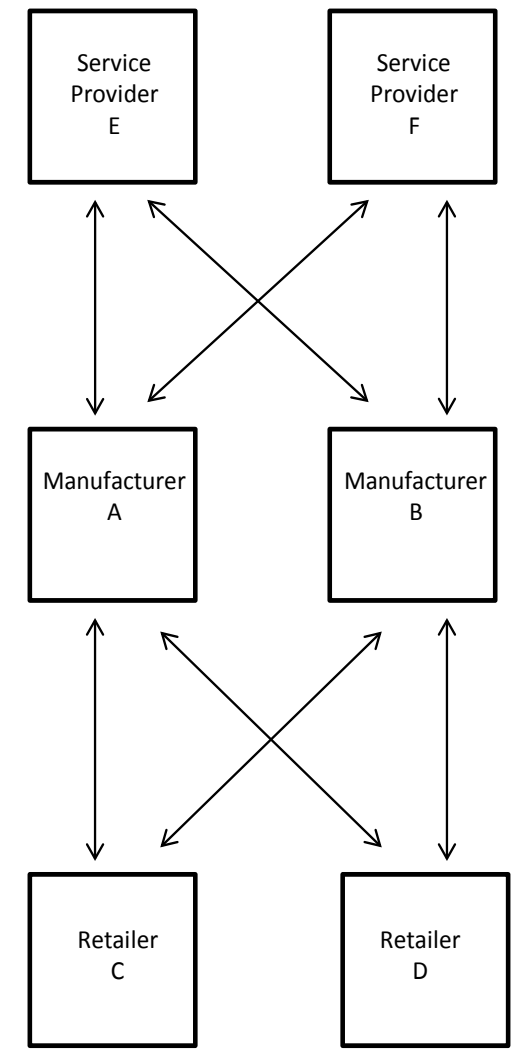


Figure 3: Number of Transactions per Annum (2011-2012)

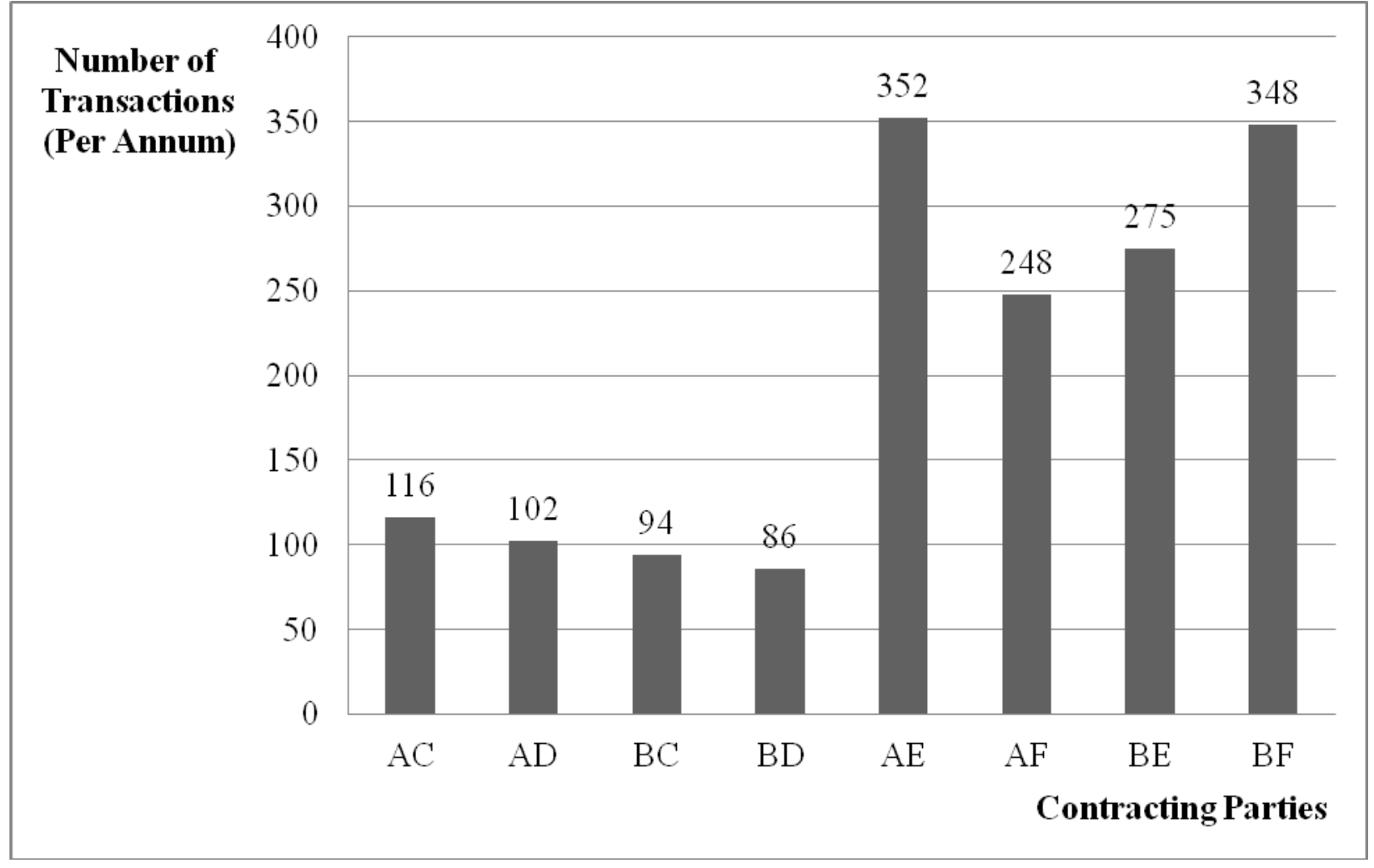

A: Multinational Consumer Goods/ pharmaceutical Firm

B: Multinational Consumer goods/ pharmaceutical Firm

C: Grocery Retail Chain

D: Grocery Retail Chain

E: Logistics Service Provider

F: Logistics Service Provider 
Table 1: Performance Targets

\begin{tabular}{|l|l|l|l|l|l|l|l|l|l|}
\hline \multicolumn{1}{|c|}{$\begin{array}{c}\text { PERFORMANCE } \\
\text { TARGETS }\end{array}$} & MEASURE & AC & AD & BC & BD & AE & AF & BE & BF \\
\hline PHYSICAL TARGETS & & & & & & & & & \\
\hline Geographical coverage & Nielsen Areas & & & & & X & X & X & X \\
\hline Shipments volume & EUR-Pallets & & & & & & & & \\
\hline R\&D targets & Prototypes & X & X & X & X & & & & \\
\hline Distribution targets & Numeric & X & X & X & X & X & X & X & X \\
\hline Property rights & Brand/Patent & X & X & X & X & & & & \\
\hline Technological systems & Standards & X & X & X & X & X & X & X & X \\
\hline MONETARY TARGETS & & & & & & & & & \\
\hline Trade allowances & & & & & & & & & \\
\hline Trade spending & Value-in-Use & $\mathrm{X}$ & $\mathrm{X}$ & $\mathrm{X}$ & $\mathrm{X}$ & & & & \\
\hline R\&D spending & Value-in-Use & $\mathrm{X}$ & $\mathrm{X}$ & $\mathrm{X}$ & $\mathrm{X}$ & & & & \\
\hline Net-net price & Value-in-Use & $\mathrm{X}$ & $\mathrm{X}$ & & & $\mathrm{X}$ & & $\mathrm{X}$ & \\
\hline Delay of payments & Value per unit & $\mathrm{X}$ & $\mathrm{X}$ & & & $\mathrm{X}$ & $\mathrm{X}$ & $\mathrm{X}$ & $\mathrm{X}$ \\
\hline Space profitability & In days & $\mathrm{X}$ & $\mathrm{X}$ & $\mathrm{X}$ & $\mathrm{X}$ & $\mathrm{X}$ & $\mathrm{X}$ & $\mathrm{X}$ & $\mathrm{X}$ \\
\hline
\end{tabular}




\begin{tabular}{|l|l|l|l|l|l|l|l|l|l|}
\hline Capital investments & $\begin{array}{l}\text { Return on } \\
\text { Assets }\end{array}$ & & & & & $\mathrm{X}$ & $\mathrm{X}$ & $\mathrm{X}$ & $\mathrm{X}$ \\
\hline Informational Targets & & & & & & & & & \\
\hline Electronic data interchange & Units (SKU) & $\mathrm{X}$ & $\mathrm{X}$ & $\mathrm{X}$ & $\mathrm{X}$ & $\mathrm{X}$ & $\mathrm{X}$ & $\mathrm{X}$ & $\mathrm{X}$ \\
\hline Continuous stock replenishment & Units (SKU) & $\mathrm{X}$ & $\mathrm{X}$ & $\mathrm{X}$ & $\mathrm{X}$ & $\mathrm{X}$ & $\mathrm{X}$ & $\mathrm{X}$ & $\mathrm{X}$ \\
\hline Scanner off-take data & Units (SKU) & $\mathrm{X}$ & $\mathrm{X}$ & $\mathrm{X}$ & $\mathrm{X}$ & $\mathrm{X}$ & $\mathrm{X}$ & $\mathrm{X}$ & $\mathrm{X}$ \\
\hline Shopper-insight & Basket Value & $\mathrm{X}$ & $\mathrm{X}$ & & & & & & \\
\hline Category data & Value & $\mathrm{X}$ & $\mathrm{X}$ & & & $\mathrm{X}$ & & $\mathrm{X}$ & \\
\hline Efficient consumer response & $\begin{array}{l}\text { Savings/ } \\
\text { Time }\end{array}$ & $\mathrm{X}$ & $\mathrm{X}$ & $\mathrm{X}$ & $\mathrm{X}$ & $\mathrm{X}$ & $\mathrm{X}$ & $\mathrm{X}$ & $\mathrm{X}$ \\
& & & & & & & & & \\
\hline
\end{tabular}


Table 2: Performance-based Contract Clauses

\begin{tabular}{|c|c|c|c|c|c|c|c|c|c|}
\hline Relevant Areas & Contract Clauses & AC & AD & BC & BD & AE & AF & $\mathbf{B E}$ & BF \\
\hline Volume / Prices & $\begin{array}{l}\text { Volume and Prices to be agreed } \\
\text { Continuous monitoring of consumer off-take data }\end{array}$ & $\mathrm{X}$ & $\mathrm{X}$ & $\mathrm{X}$ & $\mathrm{X}$ & & & & \\
\hline Termination Rights & $\begin{array}{l}\text { Each party has the right to terminate the agreement giving one year's } \\
\text { prior notice }\end{array}$ & $\mathrm{X}$ & $\mathrm{X}$ & $\mathrm{X}$ & $\mathrm{X}$ & & & & \\
\hline Subcontracting & $\begin{array}{l}\text { Parties are not allowed pass on performance of agreed duties to a 3rd } \\
\text { party, unless a written consent has been obtained. }\end{array}$ & & & & & $\mathrm{X}$ & $\mathrm{X}$ & $\mathrm{X}$ & $\mathrm{X}$ \\
\hline Saving Clause & $\begin{array}{l}\text { Unless it is of major importance, invalidity of one or more clauses } \\
\text { will not have any effect on the agreement as a whole }\end{array}$ & $\mathrm{X}$ & $\mathrm{X}$ & $\mathrm{X}$ & $\mathrm{X}$ & & & & \\
\hline Property Rights & Supplier ensures that no third person has obtained property rights & $\mathrm{X}$ & $\mathrm{X}$ & $\mathrm{X}$ & $\mathrm{X}$ & & & & \\
\hline $\begin{array}{l}\text { Product/Service } \\
\text { Category }\end{array}$ & Consumer goods/ pharmaceuticals & $\mathrm{X}$ & $\mathrm{X}$ & $\mathrm{X}$ & $\mathrm{X}$ & $\mathrm{X}$ & $\mathrm{X}$ & $\mathrm{X}$ & $\mathrm{X}$ \\
\hline
\end{tabular}




\begin{tabular}{|c|c|c|c|c|c|c|c|c|c|}
\hline $\begin{array}{l}\text { Notification } \\
\text { Requirements }\end{array}$ & Mutual notification regarding all future capital investment and R\&D & $\mathrm{X}$ & $\mathrm{X}$ & $\mathrm{X}$ & $\mathrm{X}$ & & & & \\
\hline Legal Venue & London / Zurich & $\mathrm{X}$ & $\mathrm{X}$ & $\mathrm{X}$ & $\mathrm{X}$ & & & & \\
\hline Information Flow & It is agreed to establish an Electronic Data Interchange & $\mathrm{X}$ & $\mathrm{X}$ & $\mathrm{X}$ & $\mathrm{X}$ & $\mathrm{X}$ & $\mathrm{X}$ & $\mathrm{X}$ & $\mathrm{X}$ \\
\hline Exclusivity & Parties have the right to obtain competitive offers at any time & & & & & $\mathrm{X}$ & $\mathrm{X}$ & $\mathrm{X}$ & $\mathrm{X}$ \\
\hline Duration & Indefinite Agreement (IA) updated annually on a rolling basis & IA & IA & IA & IA & IA & IA & IA & IA \\
\hline Arbitration/ & International Chapter of Commerce & $\mathrm{X}$ & $\mathrm{X}$ & $\mathrm{X}$ & $\mathrm{X}$ & $\mathrm{X}$ & $\mathrm{X}$ & $\mathrm{X}$ & $\mathrm{X}$ \\
\hline
\end{tabular}




\begin{tabular}{|l|l|l|l|l|l|l|l|}
\hline Mediation & & & & & & & \\
\hline \\
Confidentiality & $\begin{array}{l}\text { All information exchanged is confidential and shall not to be } \mathrm{X} \\
\text { available to third parties without written consent of the other party }\end{array}$ & $\mathrm{X}$ & $\mathrm{X}$ & $\mathrm{X}$ & $\mathrm{X}$ & $\mathrm{X}$ & $\mathrm{X}$ \\
\hline
\end{tabular}


Table 3: Analysis of Performance-based Contracting

\begin{tabular}{|c|c|}
\hline Performance Outcomes & Counterparts' Consent \\
\hline Contractual Effectiveness & $\begin{array}{l}\text { - Continuous monitoring of consumer off-take data } \\
\text { - Continuous monitoring of brand awareness, } \\
\text { consumer penetration and distribution levels by a } \\
3^{\text {rd }} \text { parties (GfK, ACNielsen } \\
\text { - Subcontracting is only possible upon consent } \\
\text { - Unless it is of major importance, invalidity of one } \\
\text { or more clauses will not have any effect on the } \\
\text { agreement as a whole } \\
\text { - Parties have the right to obtain competitive offers } \\
\text { at any time } \\
\text { - It is agreed a Vendor-Managed Inventory } \\
\text { All information exchanged is confidential and } \\
\text { shall not to be available to third parties without } \\
\text { written consent of the other party }\end{array}$ \\
\hline Contractual Efficiency & $\begin{array}{l}\text { - Payment in } 30 \text { days; delivery cost is paid by the } \\
\text { supplier. } \\
\text { - Variable value-based pricing; value-in-use } \\
\text { - Listing fees for all new product/service } \\
\text { introductions } \\
\text { - Mutual notification regarding all future capital } \\
\text { investment and R\&D } \\
\text { - It is agreed to establish an Electronic Data } \\
\text { Interchange } \\
\text { - It is agreed continuous stock replenishment }\end{array}$ \\
\hline Contractual Risk & $\begin{array}{l}\text { - Parties are not allowed pass on performance of } \\
\text { agreed duties to a 3rd party. } \\
\text { - The obligation to remedy deficiencies applies also } \\
\text { to services obtained from subcontractors } \\
\text { - Annual Renegotiation/ Quarterly Business } \\
\text { Reviews (QBR) } \\
\text { - Supplier ensures that no third person has obtained } \\
\text { property rights } \\
\text { - Parties bear no liability for damages occurred as a } \\
\text { result of war, political unrest, strikes, lockouts, } \\
\text { and governmental interventions (exclusion terms) } \\
\text { - Arbitration through the International Chapter of } \\
\text { - Commerce } \\
\text { - Volume and Prices to be agreed }\end{array}$ \\
\hline
\end{tabular}


